\title{
Accompaniment On Parents In Increasing Children's Learning Interest In The Covid-19 Pandemic
}

\author{
M. Dahlan $\mathrm{R}^{1^{*}}$, Rizcka Fatiya ${ }^{2}$ \\ 1. 2 Departemen of Islamic Studies Universitas Ibn Khaldun Bogor. Indonesia \\ * Corresponding Author: \\ Email: dahlan@uika-bogor.ac.id
}

\begin{abstract}
.
This guidance aims to: (1) encourage student guardians to increase their children's interest in learning during the Covid-19 pandemic at SDN Dukuh 01; (2) identify ways to increase student interest in learning during the Covid-19 pandemic at SDN Dukuh 01; and (3) raise parents' awareness of the importance of their children's education. The guardianship training was done via a WhatApp group that included parents and guardians of grade 2 and 3 pupils at SDN Dukuh 01, totaling 48 guardians. Parents frequently accompany their children to study at home, according to the findings of processing the questionnaire data given after the parents have finished coaching 80 percent of the pupils. And $70 \%$ of parents frequently motivate their children at home while they are learning. 70 percent of parents and guardians of students establish a comfortable environment for their children to study at home, and 60 percent of parents vary and innovate their children's everyday activities at home to increase their children's interest in learning.
\end{abstract}

Keywords: Covid-19; Learning Interest; Student Guardian,

\section{INTRODUCTION}

Education is vital to human life and cannot be separated from it. According to Article 1 paragraph 1 of Law No. 20 of 2003 Concerning the National Education System, education is a purposeful and planned endeavor to create a learning environment and learning process in which students actively develop their capacity for religious spiritual strength. self-control, personality, intelligence, noble character, and the abilities that he, society, nation, and state require. (Novrinda, Kurniah, and Yulidesni 2017)(Raharjo 2010).There are many types of efforts, including teaching, that are made by someone (educator) to someone (students) in order to achieve maximum positive development. These efforts include developing knowledge and skills, providing examples (examples) to be imitated, familiarizing, praise and gifts, and so on.The COVID-19 pandemic is a calamity that affects the entire world's population. All aspects of human existence on the planet have been affected, including education. Many countries, including Indonesia, have decided to close schools, colleges, and institutions.(Aji 2020).

COVID-19 is the most recent sickness, making it a pandemic. (Bulut and Kato 2020). This is a contagious disease that spreads quickly enough that it has a high fatality rate that cannot be overlooked before it is fatal. (Susilo et al. 2020). Since the outbreak of the Corona virus in Indonesia in early March, (Yunus and Rezki 2020), 
forced the government to take serious action to prevent a larger spread, therefore the government made several attempts to prevent a very wide spread, one of which was to adopt remote learning at all levels, from elementary to tertiary.

The Covid-19 epidemic has two effects on the long-term viability of education. The first is the immediate impact, which many Indonesian families are experiencing in both urban and rural locations. Many Indonesian families are unaccustomed to conducting schoolwork at home. Homeschooling is a major surprise for Indonesian families, especially for the productivity of parents who are normally working outside the home. Similarly, pupils who are used to studying from their lecturers face to face may experience psychological issues. (Aji 2020).The Covid-19 epidemic has shifted the learning pattern from face-to-face to distance learning, sometimes known as online. One of the challenges in this online learning system is a lack of technological understanding.(Sadikin and Hamidah 2020). In this context, parents, in particular, are expected to assist their children through this internet-based learning. It may not be an issue for parents who are used to using technology, but it can be difficult for parents who are new to using technology to guide their children in this situation.It is undoubtedly difficult for all aspects of school, particularly parents, to adjust to this new learning method. Prior to this condition, parents did not have much time to guide their children, to the point where they were simply there to provide material comfort. But things have changed this time; parents now have more time to guide their children, and there is a greater emotional bond than previously.(Cahyati and Kusumah 2020) Because parents are the family's closest members, the family has a significant impact on a child's desire to learn.

What a child receives from his or her family has a significant impact on his or her mental development. It is vital to support attention and advice from the family, particularly parents, in order to increase their children's interest in learning during the process of developing interest.Parents bear the primary responsibility for their children's growth and development. Parental education, whether good or bad, has an impact on the child's development and growth.(Lilawati 2020). For each child, the home setting, all conduct, and what appears in the child will all mimic his parents. As a result, parents play a critical role in their children's lives. (Fadillah, 2012:35) in the creation of a conducive learning environment A pleasant, non-threatening learning environment, with an encouraging and optimistic attitude toward students' learning, encourages someone to be engaged in learning, tolerates a competitive environment, and is unconcerned about failure.(Suprihatin 2015). Furthermore, parents must be able to pay attention to their children; this will undoubtedly improve their enthusiasm in studying. (Fauziah, Rosnaningsih, and Azhar 2017). When a child is motivated, his or her interest will be piqued. Interest, according to D.P. Tampubolon, is "a mixture of desire and ability that can emerge if motivation exists." The acceptance of a relationship between oneself and something outside oneself is what interest is all about; the stronger or closer the relationship, the higher the interest.(Noviana, 
Rabbanie, and Nawawi 2020). Interest is always followed by pleasant feelings, and then a decision is made. (Nursyaidah 2014) As a result, a student's level of interest is critical. (Kartika, Husni, and Millah 2019).

The service was carried out in Hamlet Village, Cibungbulang District, Bogor Regency. The people who were there, especially the parents, did not give their children time to study, so that during this covid-19 pandemic, which required children to study at home, but they only played every day, and considered distance learning or learning at home as an opportunity. holidays, and children also lack guidance, support and supervision from parents in carrying out this distance learning, so this service is also focused on the guardians of students at SDN Dukuh 01.The objectives to be achieved in this service are: (1) To foster parents / guardians of students in increasing children's interest in learning during the covid-19 pandemic through WhatApp Groups. (2) To find ways to increase student interest in learning during the covid-19 pandemic. (3) To increase parents' awareness of the importance of children's education. So that parents do not neglect their children's education, especially when children are required to study at home.

\section{METHODS}

The guardianship training was conducted through a WhatApp group that included parents and guardians from grade 2 and 3 elementary schools, totaling 48 guardians at SDN Dukuh 01. This training lasted two weeks, from September 7 to 14, 2020. With two stages of implementation: the first stage, which is the socialization of knowledge about covid-19 and how to overcome it. The second stage consists of providing the first three materials, namely material on the role of parents in children's education during the covid-19 pandemic, the second material, namely material on how to accompany children to study at home, and the third material, namely material on how to accompany children to study at home. material on how to help children focus on learning at home, and third, material on how to help children focus on learning at home. To assess the guardians' aptitude and comprehension, after the WhatApp coaching, the group was given questionnaires and several parents were interviewed about the content I had presented.

\section{RESULT AND DISCUSSION}

In the process of developing interest, it is necessary to support attention and guidance from the family, especially parents, in increasing their children's interest in learning. To arouse children's interest in learning, it is necessary to provide an understanding of: (a) why it should be studied (b) what the material is studied for (c) how to learn it. Problem solving that can be done is to provide knowledge, understanding, and guidance on how parents and guardians of students increase their interest in learning during the COVID-19 pandemic given to parents and guardians of students in Dukuh Village, Cibungbulang District.After discussing through interviews 
with homeroom teachers regarding how the parents of the students were when they were guiding their children to study at home, it can be concluded that there are some parents who are having difficulties and there are a lot of complaints from the parents regarding their children who are carrying out in this home learning, many children are bored and bored at home, so their children just play and play, so they forget to learn. And parents are very confused about how to increase their child's interest in learning.

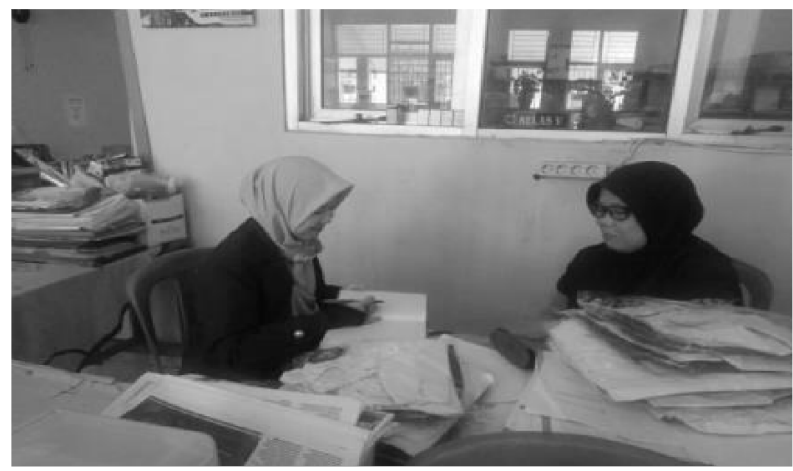

Fig 1. Interview with Mrs. Ela as the homeroom teacher.

Due to the current issues, parental guardianship was established through Whatapp groups, and I gave information on how parents can improve their children's enthusiasm in learning during the Covid-19 pandemic.The content for this coaching was provided in two parts, the first of which was knowledge diffusion linked to the comprehension of covid-19, which contained questions such as: what is covid 19? Where did Covid-19 originate? How long does it take for covid-19 to incubate? What is the risk level of Covid-19? What are the clinical signs of COVID-19 and how to cope with them, including how to wear a mask and follow health regulations at all times?The second stage is to provide the first 3 materials, namely material about the role of parents in children's education during the covid-19 pandemic, which explains that the role of parents is as a guide, educator, guard, during this pandemic of course the role of parents is to maintain and ensure their children live clean and healthy. And parents also play a role in assisting children in learning at home while doing work that must be done at home such as taking care of the house or parents carrying out WFH (Work from Home). The second material is material on how to accompany children to study at home with MIKIR (Rachmy Diana 2020) ), there are:

$\mathbf{M}=$ Helping children to schedule activities, that is, helping children to schedule activities, and providing opportunities for children to make their own schedules. This will help the child to be responsible for all planned activities to be carried out.

I = Activity Idea, namely, as a parent, you have to provide activity ideas with several things you can do besides doing tasks, such as: daily activities, physical activities, learning activities or other activities. 
$\mathbf{K}=$ Positive communication when starting, namely, helping children understand what to do, if we as parents find it difficult then we can contact the teacher again via phone, sms, or whatapp to ask for an explanation regarding the child's task.

$\mathbf{I}=$ Remind the time, that is, the schedule of activities and times that will, are being, and have been used by children; reminding youngsters of planned activities can help them reach learning goals.

$\mathbf{R}=$ Daily reflection, that is, asking how he feels, what he has accomplished and what he has not accomplished, can be done on a daily basis. And, if necessary, listen to their stories, congratulate them on their accomplishments for the day, and offer comments and ideas to the children.

And the third is material on how to help children focus on learning at home. These include: (1) Being near children when studying (2) making Susana comfortable in learning (3) Aligning between learning and playing (4) Motivating children to be activeThe Covid-19 pandemic, which has occurred in almost all parts of the world, shows the increasing importance of the role of the family in nurturing, caring for and educating children. This event restores the initial function of the family as the center of all activities, where the main education for children takes place. The family cannot be separated from the child's life, which is the main and first place in starting his life. Within the family, values, religion, morals, and social values can be carried out more effectively than in other institutions. As explained by one of the students' parents when interviewed according to him:

"Basically, children's education starts at home, so basic education comes from mother and father or parents. We don't just educate children at home, we also have to educate children, because parents are the first and foremost madrasa for their children before they go out looking for knowledge."

From the results of processing the questionnaire data given after the parents have finished coaching $80 \%$ of the students, they often accompany their children to study at home. And $70 \%$ of parents often motivate their children during learning at home. From the results of the questionnaire that many parents help motivate and accompany their children as long as their children are required to study from home because of the government's appeal regarding covid-19, this is also what makes not a few parents deliberately take the time to help their child's learning process during at home.

Many parents agree that during learning at home, it is the parents who also help their children in learning at home.The results of interviews with parents showed that parents inevitably have to be able to become intermediaries between teachers and children in learning during a pandemic and parents inevitably have to accompany their children while studying in the midst of economic and work difficulties faced by parents. 


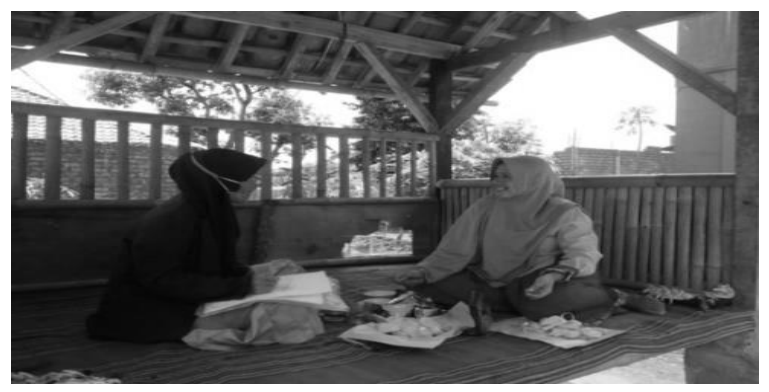

Fig 2. Interview with Ibu Pipih as a parent

In increasing children's interest in learning, from the results of processing questionnaire data, $70 \%$ of parents and guardians of students often create a comfortable environment for their children to study at home and $60 \%$ of parents often carry out variations and innovations in children's daily activities at home.From the results of the questionnaire that parents can develop activities at home by providing a variety of activities and carrying out various innovations while at home, a variety of activities carried out by parents is needed to maintain good interactions in child care. This variation is not only intended for children, but also for the parents themselves. To keep children learning fun, parents also need to have fun experiences or activities as well.

The role of affection in addressing the needs and comfort of children so that their interest in learning grows is one of the characteristics that can promote the success of the parent's role in positive parenting.As explained by one of the students' parents when interviewed according to him:

"My husband and I don't have to study seriously at home, but we can learn by playing, such as singing, guessing and guessing. So we as parents create learning that is not just books, so that children are comfortable in learning. Because during this pandemic we have to stay at home, so how do we as parents create learning that is not boring for our children?"

\section{CONCLUSION}

The fostering of student guardians, which has been conducted out through this WhatsApp group, has been able to provide knowledge and awareness for parents and guardians of students in order to increase their children's desire in learning throughout the covid-19 pandemic. As a result, the family has a strong influence on how interested youngsters are in studying. The role of parents is very important for the learning process of children, and parents must be able to increase their children's interest in learning so that their children become the next best generation, with this understanding of parents, so that parents remember how important the role of parents in educating children is. The advice that can be given is that parents must carry out positive parenting for their children, one dimension that can support the success of the parent's role here is the role of love in meeting the needs and comfort of children so that their interest in learning increases. 


\section{ACKNOWLEDGMENTS}

We are grateful to SDN Dukuh 01's principal and homeroom teacher for allowing us to provide guidance to parents and guardians of students via Whatapp groups in order to provide knowledge and understanding of parents and guardians of students in order to increase children's interest in learning during the covid-19 pandemic. Thank you also to Mr. Rofi'i, the head of RT kp. Cimangir Jalan RT03/RW06, Cibungbulang District, Bogor Regency, for including and allowing parents and guardians of students to participate in this coaching. Hopefully, what has been done will be valuable to parents in increasing their children's interest in studying, particularly in light of the current covid-19 pandemic.

\section{REFERENCES}

[1] Aji, Rizqon Halal Syah. 2020. "Dampak Covid-19 Pada Pendidikan Di Indonesia: Sekolah, Keterampilan, Dan Proses Pembelajaran.” Salam: Jurnal Sosial dan Budaya Syar-i.(7) 5: 395-402.

[2] Bulut, Cemal, and Yasuyuki Kato. 2020. "Epidemiology of Covid-19." Turkish Journal of Medical Sciences 50(SI-1).

[3] Cahyati, Nika, and Rita Kusumah. 2020. "Peran Orang Tua Dalam Menerapkan Pembelajaran Di Rumah Saat Pandemi Covid 19." Jurnal Golden Age 4(01): 152-59.

[4] Fauziah, Amni, Asih Rosnaningsih, and Samsul Azhar. 2017. "Hubungan Antara Motivasi Belajar Dengan Minat Belajar Siswa Kelas IV SDN Poris Gaga 05 Kota Tangerang.” Jurnal JPSD 4(1): 47-53.

[5] Kartika, Sinta, Husni Husni, and Saepul Millah. 2019. "Pengaruh Kualitas Sarana Dan Prasarana Terhadap Minat Belajar Siswa Dalam Pembelajaran Pendidikan Agama Islam." Jurnal Penelitian Pendidikan Islam,[SL] 7(1): 113-26.

[7] Lilawati, Agustin. 2020. "Peran Orang Tua Dalam Mendukung Kegiatan Pembelajaran Di Rumah Pada Masa Pandemi.” Jurnal Obsesi: Jurnal Pendidikan Anak Usia Dini 5(1): $549-58$.

[9] Noviana, Della, Muhammad Dahlan Rabbanie, and H M Kholil Nawawi. 2020. "Kreativitas Guru MI Nurul Hidayah Dalam Meningkatkan Minat Belajar Siswa Untuk Membentuk Siswa Berprestasi." Jurnal Gentala Pendidikan Dasar 5(1): 62-77.

[10] Novrinda, Novrinda, Nina Kurniah, and Yulidesni Yulidesni. 2017. "Peran Orangtua Dalam Pendidikan Anak Usia Dini Ditinjau Dari Latar Belakang Pendidikan.” Jurnal Ilmiah Potensia 2(1): 39-46.

[11] Nursyaidah, Nursyaidah. 2014. "Faktor-Faktor Yang Mempengaruhi Belajar Peserta Didik." In Forum Paedagogik,

[12] Rachmy Diana. 2020. "Peran-Orang-Tua-Dalam-Pendidikan-Anak-Masa-Pandemi." https://s3ppi.umy.ac.id/wp-content/uploads/2020/06/.

[13] Raharjo, Sabar Budi. 2010. "Pendidikan Karakter Sebagai Upaya Menciptakan Akhlak Mulia." Jurnal Pendidikan dan Kebudayaan 16(3): 229-38.

[14] Sadikin, Ali, and Afreni Hamidah. 2020. "Pembelajaran Daring Di Tengah Wabah Covid19." Biodik 6(2): 214-24.

[15] Suprihatin, Siti. 2015. "Upaya Guru Dalam Meningkatkan Motivasi Belajar Siswa." Jurnal Pendidikan Ekonomi UM Metro 3(1): 73-82.

[16] Susilo, Adityo et al. 2020. "Coronavirus Disease 2019: Tinjauan Literatur Terkini." Jurnal Penyakit Dalam Indonesia 7(1): 45-67.

[17] Yunus, Nur Rohim, and Annissa Rezki. 2020. "Kebijakan Pemberlakuan Lock Down Sebagai Antisipasi Penyebaran Corona Virus Covid-19." Salam: Jurnal Sosial dan Budaya Syar-i 7(3): 227-38. 